DOI 10.37882/2223-2982.2020.05.29

\title{
«ПАЛКА О ДВУХ КОНЦАХ»: КОММУНИКАТИВНЫЕ НЕУДАЧИ ИСПОЛЬЗОВАНИЯ ИДИОМАТИЧЕСКИХ ВЫРАЖЕНИЙ В МЕДИАДИСКУРСЕ
}

\section{"A DOUBLE-EDGED SWORD": COMMUNICATIVE FAILURES OF USING IDIOMATIC EXPRESSIONS IN MEDIA DISCOURSE}

\section{E. Polyakova \\ N. Shchitova}

Summary: The paper is devoted to the topical problem of studying Russian idiomatic expressions in use and linguistic and extralinguistic causes of their actualization in media discourse. Considerable attention is paid to the study of communicative failures, caused by the use of idioms by foreign speakers in the political media space. It is noted that the use of idiomatic expressions especially proverbs and sayings reveals the identification "friend-or-foe".

Keywords: communication, communicative failures, addresser, addressee, media discourse, idiomatic expression, proverb.

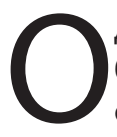

дним из основных условий эффективности работы средств массовой коммуникации является согласованность взаимодействия автора и адресата, которая реализуется посредством идентичности или частичного совпадения ментальных, лингвокогнитивных, концептуальных сфер коммуникантов.

Настоящее исследование посвящено анализу коммуникативных неудач, вызванных использованием идиоматических выражений в медиадискурсе, и стратегиям их употребления.

Интерес к выявлению особенностей идиоматических выражений и стратегий их использования в различных дискурсах не ослабевает, что свидетельствует о многоаспектности исследуемой проблемы и делает предложенную тему актуальной, обладающей определенной новизной и практической ценностью.

Выявление факторов возникновения коммуникативных неудач, возникающих при использовании идиоматических выражений разных уровней абстракции в медиадискурсах политической направленности является целью исследования.

В качестве методов исследования используются ме-
Полякова Елена Владимировна

К.филол.н., профессор, Таганрогский институт имени А.П. Чехова (филиал) ФГБОУ ВО «РГЭУ (РИНХ)» polyak.lena@mail.ru

Щитова Наталья Георгиевна К.филол.н., дочент, Таганрогский институт имени А.П. Чехова

(филиал) ФГБОУ ВО «РГЭУ (РИНХ)» natali2670@mail.ru

Аннотация: Статья посвящена актуальной проблеме исследования идиоматических выражений русского языка, вызывающих проблемы их использования в дискурсе, обусловленные экстралингвистическими и лингвистическими факторами. Значительное внимание уделяется исследованию коммуникативных неудач и сбоев, возникающих при употреблении пословиц и поговорок в политическом медиапространстве. Выявлено, что употребление идиоматических выражений инофонами выявляет дихотомию «свой/ чужой» в дискурсе.

Ключевые слова: коммуникация, коммуникативные неудачи, автор, адресат, медиадискурс, идиоматическое выражение, паремия.

тод сплошной выборки, описательный метод, включающий наблюдение исследуемых феноменов и явлений, обобщение и интерпретацию анализируемого материала.

Практическая значимость работы заключается в возможности использования ее результатов в исследованиях по лингвокультурологии, теории дискурса, межкультурной коммуникации, а также при обучении спич- и копирайтеров.

Для успешной коммуникации необходимо учитывать ассоциативно-смысловые поля языковой личности адресата, которые выявляются в процессе восприятия и понимания лексикона любого дискурса, являющегося центром семантической сети, вокруг которой группируются и другие единицы высказывания. Выявленную закономерность объясняют рядом факторов, основным из которых является учет личности адресата. При условии совпадения ассоциативно-смысловых полей адресанта и адресата достигается единство в интерпретации событийных факторов, что является важным фактором эффективности дискурса. Стратегии успешной коммуникации состоят как в правильном использовании речевых средств в построении речевой цепи, так и совпадении образов сознания, которые отображают предметы 
конкретной национальной культуры. Для достижения взаимопонимания необходим «общий фонд знаний и верований, иначе говоря, у коммуникантов в феноменологическом поле должен присутствовать общий набор контекстуальных пропозиций - общий пресуппозиционный фонд, без которого совместная деятельность порождения и понимания дискурса затруднена или невозможна» [цит. по 3, с. 178]. Члены конкретного лингвокультурного сообщества (ЛКС), основываясь на этом пресуппозиционном фонде, способны оценивать то или иное высказывание как правильное, «свое» или неправильное, вне зависимости от его языковой, системной правильности.

Достаточно часто коммуниканты в медиапространстве обращаются к идиоматическим выражениям, благодаря особенностям кумулятивной функции этих выражений и их высокой национально-культурной маркированности [4, с. 134-184]. Использование идиоматических выражений в силу их насыщенности культурной семантикой вызывает сложности в их употреблении и восприятии и может привести к их неадекватному применению, что в свою очередь может приводить к коммуникативным сбоям и неудачам. Наилучшей иллюстрацией силы использования пословиц и поговорок в речи, базирующейся на совпадениях культурных пространств автора и адресата, являются откровения американского журналиста, участника многих ток-шоу на российских каналах, М. Бома: «Может быть, я чаще говорю пословицы, чем сами русские. Самое главное, что в меру, к месту и адекватно, надеюсь. Иногда мимо кассы получается. Кстати, был случай, когда у Соловьева я сказал выражение: «Неча на НАТО пенять, коли рожа крива», и это восприняли как грубость. Потом я извинился. Это устойчивая фраза. Я просто повторил. Изменять ее я не стал бы, а человек сделал мне замечание в прямом эфире, что это не совсем хорошее выражение. Хотя не я его придумал, я его просто повторил. Я говорю, что пословицы хорошие, но иногда они меня подводят, и приходится извиняться. Но мы учимся на ошибках. Он сам мне сказал, что лучше просто три точки. То есть «Неча на НАТО пенять ...». Всем понятно, но конкретных слов нет [9] (выделено авторами статьи. - Е.П. и Н.Щ.). В данном случае отмечается конфликт в выражении и восприятии ценностных установок, запечатленных в традиционной речевой культуре использования паремиологического выражения.

Н.Н. Семененко выделяет следующие функции паремий, влияющие на стратегии их использования в дискурсе: паремии «выражают ценностные установки, отраженные в традиционной речевой культуре народа; сохраняют моральные принципы и предлагают способы выхода на компромиссную мораль; обеспечивают способы представления действительности через призму смеховой культуры народа; реализуют способность на примере типичной ситуации сделать вывод о базовых принципах устройства этнического сообщества и человеческого общества в целом» [5]. Фактически являясь чужой речью, фрагментом языковой картины мира, пословицы и поговорки обладают большой силой воздействия на собеседника или на избранную для общения аудиторию, поскольку являют собой процесс отражения человеком содержания высказывания при непосредственном воздействии на органы чувств.

Адекватное употребление идиоматических выражений в медиадискурсе предполагает знание о ситуации, в которой их можно использовать, или наличие элементарных фоновых знаний, которые являются условием успешной коммуникации в процессе восприятия информации. Сила воздействия паремий может быть как конструктивной, так и деструктивной, то есть паремии могут быть «палкой о двух концах», и коммуникативный акт с их использованием может окончиться и «хорошо» и «плохо». Чтобы социализироваться, стать членом того или иного лингвокультурного сообщества, инофону необходимо присвоить не только опыт, накопленный членами данного сообщества, достижения материальной и духовной культуры, но также и систему норм и оценок, детерминирующих модели социального поведения [2, с. 43].

Успешная коммуникативная стратегия приводит к достижению более или менее полного взаимопонимания между коммуникантами, при неуспешной коммуникативной стратегии происходят коммуникативные сбои. Для успешной коммуникации необходимо наличие определенной общности фонда знаний и социального опыта коммуникантов и знакомство с одними и теми же элементами когнитивной базы того ЛКС, на языке которого осуществляется общение [3, с. 173-174; с. 182]. На этом уровне начинает работать принцип разграничения «свой/чужой».

Таким образом, в силу насыщенности культурной семантикой использование паремиологических единиц может приводить к коммуникативным неудачам, а их неадекватное употребление провоцирует сбои в коммуникации и даже межкультурные конфликты [2, с. 52]. Коммуникативные неудачи неоднородны по уровню воздействия на адресата в коммуникативной ситуации. Понятие коммуникативной неудачи, включающее в себя коммуникативный сбой, коммуникативный провал и коммуникативную помеху, является более широким. Коммуникативная неудача имеет результативный характер, тогда как коммуникативная помеха и коммуникативный сбой вполне поправимы при наличии желания и прилагаемых усилий со стороны собеседников [8, с. 10-11]. При комплексном подходе к изучению нарушения акта коммуникации, в своем исследовании Л.Л. Славова приводит подробную классификацию сбоев дискурса, выделяя: КН языкового характера, где ключевую роль играют неадекватный выбор лексических единиц, ошибочный выбор 
грамматической формы слова, неправильное или нечеткое произношение и неправильное восприятие или незнание лексических единиц и/или их грамматических форм соответственно говорящим или слушающим; КН peчевого характера, обусловленные нарушениями постулатов Г.П. Грайса [1, с. 217-237], отсутствие должного внимания к которым приводит к возникновению ситуаций непонимания в процессе общения; КН лингвокогнитивного характера, которые можно объяснить различием в концептуальных и языковых картинах мира коммуникантов; КН паралингвистического характера, возникающие из-за несоответствия невербальных средств вербальному процессу общения [6]. На сегодняшний день имеется целый ряд работ, посвященных рассмотрению феномена КН, краткий обзор которых дает представление о многообразии подходов к исследованию данного феномена, различных понятий, которые лингвисты вкладывают в термин КН [см.: 7, с. 216-217].

Примером коммуникативного сбоя может служить жесткое высказывание премьер-министра Австралии Тони Эббота, который использовал футбольный термин shirtfront, означающий жесткий прием, когда один игрок сбивает другого. В русском языковом сознании термин приобрел ассоциацию с фразеологизмом «взять коголибо за грудки» и «положить на лопатки», подразумевающем, что оппонент собирается выдвинуть такие обвинения, на которые у нас нет оправданий. В результате термин приобрел дополнительное значение «схватить кого-либо за рубашку в агрессивной манере, обычно перед тем, как кого-либо оскорбить или обругать» и «выступить против кого-либо с недовольством и жалобами» [16]. Способность идиоматики обеспечить способы представления действительности через призму смеховой культуры народа, позволило россиянам воспринять высказывание Т. Эббота в отношении его разговора с В. Путиным «в лучшем случае в юмористическом ключе». Тем не менее, в посольство стали поступать письма от граждан Австралии с извинениями за слова своего премьера в адрес Путина [17].

Таким образом, одним из основных условий эффективности работы средств массовой коммуникации является согласованность взаимодействия автора и адресата, которая реализуется посредством идентичности или частичного совпадения ментальных, лингвокогнитивных, концептуальных сфер и культурных пространств коммуникантов.

Коммуникативные неудачи могут возникать как в монокультурной, так и межкультурной коммуникации (см. работы О.П. Ермаковой, Е.А. Земской, С.И. Виноградова, Н.И. Формановской, Г.Г. Почепцова, Д.Б. Гудкова и др.). Коммуникативные неудачи в межкультурной коммуникации (МКК) могут быть вызваны недостаточным владением инофоном русскими семиотическими систе- мами, а могут быть вызваны как когнитивными аспектами личности коммуникантов, принадлежащими разным национальным культурам, так и неудачи, вызванные прагматическими факторами самого разного типа [2, с. 58]. Коммуникативные неудачи в МКК провоцируются невладением инофоном системой значений той культуры, на языке которой ведется общение [ibid, c. 59]. Другими словами, дискурсивные ошибки (термин Гудкова, с. 71) вызваны не незнанием системы языка, а неверным использованием инофоном системы культурных норм и ценностей того сообщества, на языке которого ведется общение.

Примером коммуникативной неудачи, вызванной нарушением системы культурных норм и ценностей русскоязычного ЛКС, является использование идиоматического выражения «мы в ответе за тех, кого приручили» в высказывании Майкла Бома об Украине. «Любовь к русским пословицам привела к тому, что в пятницу в эфире НТВ он проговорился, отвечая на вопрос ведущего, считает ли М. Бом, что надо продолжать помогать Украине, на что М. Бом ответил, что он считает, что мы в ответе за того, кого мы приручили» [15]. Эта фраза из сказки А. де Сент-Экзюпери «Маленький принц» призвана призывать к верности, сочувствию и доброте по отношению к близким и относится к высоким моральным ценностям. Использование во фразовом контексте глагола «проговорился» отсылает адресата к разговорному значению глагола «приручить» - внушить чувство доверия, признательности, сделать послушным [14], как когото более слабого, неразумного, зависимого. Наличие коммуникативного сбоя и противоположный эффект от применения данной фразы в высказывании М. Бома подчеркивается заглавием блога «Пословицы доведут до иугундера, или Майкл Бом проговорился» [15]. Устаревшее выражение взять на цугундер означает подвергнуть наказанию, расправе, а выражение довести до цугундера довести что-либо до крайности или подвести человека к наказанию, в данном коммуникативном акте помимо основного смысла указывает на то, что употребление идиоматических выражений может быть весьма опасным и привести к коммуникативным сбоям.

Примерами нарушения ценностных ориентиров русскоязычного ЛКС являются и такие использования идиоматических выражений в высказываниях М. Бома как: «чья бы корова мычала» [10], «Вы пудрите мне мозги» [11]; «Сам не гам и другому не дам» [12]; «Россия пудрит всем мозги» [13] и многие другие, которые вызывают агрессивную ответную реакцию русскоязычной аудитории, поскольку нарушают систему социального поведения и культурные ориентиры ЛКС.

Таким образом, анализ медиадискурсов, в которых инофоны используют идиоматические выражения, позволяет сделать следующие выводы: коммуникация 
участников медиадискурса не всегда бывает успешной; коммуникативные воздействия собеседников не всегда соответствуют правилам речевого взаимодействия, что приводит к возникновению сбоев, коммуникативных неудач, обусловленных как когнитивными аспектами лично- сти коммуникантов, принадлежащих разным культурам, так и дискурсивными неудачами, когда инофон использует идиоматические выражения сниженного характера, имеющие ограниченные сферы использования в русском ЛКС, что приводит к членению коммуникантов на свой/чужой.

\section{ЛИТЕРАТУРА}

1. Грайс Г.П. Логика и речевое общение // Новое в зарубежной лингвистике: лингвистическая прагматика. - М., 1985. - Bып. XVI. - C. $217-237$.

2. Гудков Д.Б. Теория и практика межкультурной коммуникации. - М.: ИТДГК «Гнозис», 2003. - 288 с.

3. Красных В.В. Основы психолингвистики и теории коммуникации. - М., «Гнозис», 2001. - 270 с.

4. Полякова Е.В. «Что такое хорошо и что такое плохо» в системе координат идиоматических этических концептов русского и английского лингвокультурных сообществ: Монография / Е.В. Полякова. - Saint-Louis, Missouri, USA: Publishing House Science and Innovation Center, 2014. - 264 p.

5. Семененко Н.Н. Фольклорная природа и языковой статус паремий в когнитивно-прагматическом освещении. Восточно-словянская филология: Сборник научных работ. - Выпуск 15. Языкознание. - Горловка: Издательство ГГППИИЯ, 2008. - С.102-110.

6. Славова Л.Л. Типология коммуникативных неудач: на материале соврем. англ. речи : автореф. дисс. ... канд. филол. наук. - Киев, 2000. - 19 с.

7. Щитова Н.Г. Причины возникновения коммуникативных неудач в речи современной молодежи // Филологические науки. Вопросы теории и практики. Тамбов: Грамота, 2012. - №5 (16). - С. 216-219.

8. Шпомер Е.А. Коммуникативные неудачи в диалогическом общении в соотнесенности с коммуникативными законами и типами языковой личности (на материале немецкого языка): автореф. дисс. ... канд. филол. наук. - Барнаул, 2011. - 23 с.

9. М. Бом: Конкуренция России и Америки никуда не денется [Электронный ресурс]. URL:https://life.ru/p/873565 (дата 0бращения: 04.12.2019).

10. М. Бом: Чья бы корова мычала [Электронный ресурс]. URL:https://www.youtube.com/watch?v=trBLXxt5Hрw (дата обращения 16.03.2020).

11. М. Бом: Вы пудрите мне мозги [Электронный ресурc]. URL:https://ok.ru/video/12517377450 (дата обращения 16.08.2017).

12. М. Бом: Сам не гам и другому не дам (Диалог русского с американцем А. Гордон vs M. Бом [Электронный pecypc]. URL: https://my.mail.ru/mail/valeriy.dits/ video/_myvideo/696.html (дата обращения 16.09.2019).

13. М. Бом: Россия пудрит всем мозги. [Электронный ресурс]. URL: https://russia.tv/video/show/brand_id/60851/episode_id/1436066/ (дата 0бращения 20.07.2019).

14. Евгеньева А.П. Словарь русского языка в 4-х томах, 1999. [Электронный ресурс]. URL: http://feb-web.ru/feb/mas/MAS-abc/default.asp (дата обращения: 02.12.2019).

15. Пословицы доведут до цугундера или Майкл Бом проговорился [Электронный ресурс]. URL: https://twoleadersfan.wordpress.com/2016/11/20 (дата 0бращения: 02.02.2020).

16. Тони Эббот [Электронный ресурc]. URL:https://inosmi.ru/world/20141014/223662066.html (дата обращения: 12.02.2020).

17. Тони Эббот: Взять за грудки (RGRU 14.10.2014). [Электронный ресурc]. URL:https://lenta.ru/news/2014/10/13/abbott/ (дата 0бращения: 14.02.2020).

(c) Полякова Елена Владимировна (polyak.lena@mail.ru ), Щитова Наталья Георгиевна (natali2670@mail.ru). 